\title{
Ultra-sensitive detection of prion protein fibrils by flow cytometry in blood from cattle affected with bovine spongiform encephalopathy
} Lothar Trieschmann1, Alexander Navarrete Santos"1, Katja Kaschig1, Sandra Torkler ${ }^{1}$, Elke Maas², Hermann Schätzl ${ }^{2}$ and Gerald Böhm*1

Address: ${ }^{1}$ ACGT ProGenomics AG, Weinbergweg 22, D-06120 Halle (Saale), Germany and ${ }^{2}$ Institute of Virology, Technical University of Munich, Biedersteinerstrasse 29, D-80802 Munich, Germany

Email: Lothar Trieschmann - lothar.trieschmann@acgt-progenomics.de; Alexander Navarrete Santos - alexander.navarrete.santos@acgtprogenomics.de; Katja Kaschig - katja.kaschig@acgt-progenomics.de; Sandra Torkler - sandra.torkler@acgt-progenomics.de; Elke Maas - maas@lrz.tu-muenchen.de; Hermann Schätzl - schaetzl@Irz.tum.de; Gerald Böhm* - gerald.boehm@acgt-progenomics.de

* Corresponding author

Published: 04 October 2005

BMC Biotechnology 2005, 5:26 doi:10.1 186/1472-6750-5-26
Received: 03 May 2005

Accepted: 04 October 2005

This article is available from: http://www.biomedcentral.com/I472-6750/5/26

(C) 2005 Trieschmann et al; licensee BioMed Central Ltd.

This is an Open Access article distributed under the terms of the Creative Commons Attribution License (http://creativecommons.org/licenses/by/2.0), which permits unrestricted use, distribution, and reproduction in any medium, provided the original work is properly cited.

\begin{abstract}
Background: The definite diagnosis of prion diseases such as Creutzfeldt-Jakob disease (CJD) in humans or bovine spongiform encephalopathy (BSE) in cattle currently relies on the post mortem detection of the pathological form of the prion protein (PrPSc) in brain tissue. Infectivity studies indicate that PrPSc may also be present in body fluids, even at presymptomatic stages of the disease, albeit at concentrations well below the detection limits of currently available analytical methods.

Results: We developed a highly sensitive method for detecting prion protein aggregates that takes advantage of kinetic differences between seeded and unseeded polymerization of prion protein monomers. Detection of the aggregates was carried out by flow cytometry. In the presence of prion seeds, the association of labelled recombinant PrP monomers in plasma and serum proceeds much more efficiently than in the absence of seeds. In a diagnostic model system, synthetic PrP aggregates were detected down to a concentration of approximately $10^{-8} \mathrm{nM}[0.24 \mathrm{fg} / \mathrm{ml}]$. A specific signal was detected in six out of six available serum samples from BSE-positive cattle.

Conclusion: We have developed a method based on seed-dependent PrP fibril formation that shows promising results in differentiating a small number of BSE-positive serum samples from healthy controls. This method may provide the basis for an ante mortem diagnostic test for prion diseases.
\end{abstract}

\section{Background}

A group of fatal transmissible neurodegenerative diseases, including Creutzfeld-Jakob disease (CJD), bovine spongiform encephalopathy (BSE), chronic wasting disease (CWD) and scrapie, is caused by an unusual infectious agent that has been termed prion [1]. Prions consist of an aberrant isoform ( $\mathrm{PrPSc}$ ) of the normal cellular prion protein $\left(\operatorname{PrP}^{\mathrm{C}}\right) \cdot \operatorname{PrPC}^{\mathrm{C}}$ is a cell surface glycoprotein expressed in neurons [2] and other cell types [3,4]. The precise physiological function of the cellular prion protein is not known yet. PrPsc differs from $\mathrm{PrPC}^{\mathrm{C}}$ in its higher content of $\beta$-sheet structure $[5,6]$, its partial resistance to protease digestion 
[7], and its tendency to form large aggregates [8]. PrPSc propagates by converting the cellular prion protein to the $\mathrm{PrPsc}^{\mathrm{Sc}}$ conformation [9]. PrPSc aggregates accumulate predominantly in the central nervous system (CNS), and definitive diagnosis of prion diseases currently relies on the post mortem detection of PrPSc in CNS tissue by immunohistochemistry, Western blotting, or ELISA [10]. Transmission studies indicate that prions may also be present in blood, potentially allowing for ante mortem diagnosis, but the sensitivity of the currently available analytical methods is insufficient for the detection of the extremely low prion titers that can be expected in body fluids [11].

Here, we report the development of a method based on kinetic differences between seeded and unseeded aggregation of prion protein that allows the detection of $\operatorname{PrP}$ aggregates in blood down to attomolar concentrations by flow cytometry.

\section{Results and discussion}

\section{Detection of synthetic prion protein aggregates in serum or plasma}

Kinetic differences between seeded and spontaneous polymerization of peptide monomers can be used for the detection of amyloid $\beta$-protein aggregates in the cerebrospinal fluid of Alzheimer's disease patients [15]. Here, we extend the principle of seeded polymerization to the detection of prion protein aggregates.

While trying to establish conditions for the labeling of synthetic prion protein aggregates with a fluorescently labeled prion protein probe, we observed that the formation of prion protein aggregates proceeds much less efficiently in serum or plasma (not shown) than in PBS (Fig. 1 ). This inhibition is probably caused by interactions of the prion protein probe with serum proteins.

Next, we found that the addition of preformed prion protein aggregates to plasma can partially overcome this inhibition (Fig. 2). The preformed aggregates presumably function as seeds that facilitate the formation of new aggregates in the inhibitory environment of plasma. The seeds stimulated the formation of prion protein aggregates at all concentrations tested, from $5 \mathrm{nM}[120 \mathrm{ng} / \mathrm{ml}]$ to $10^{-8} \mathrm{nM}[0.24 \mathrm{fg} / \mathrm{ml}]$ (Fig $2 \mathrm{C}$ ). The average ratio of event counts in seeded samples to those in samples without seeds was 6.4. The number of events, however, was not proportional to the seed concentration, but remained relatively constant over the whole concentration range. Thus, the seed-dependent formation of prion protein aggregates can be used to detect extremely low amounts (down to the attomolar range) of spiked prion protein aggregates in blood.
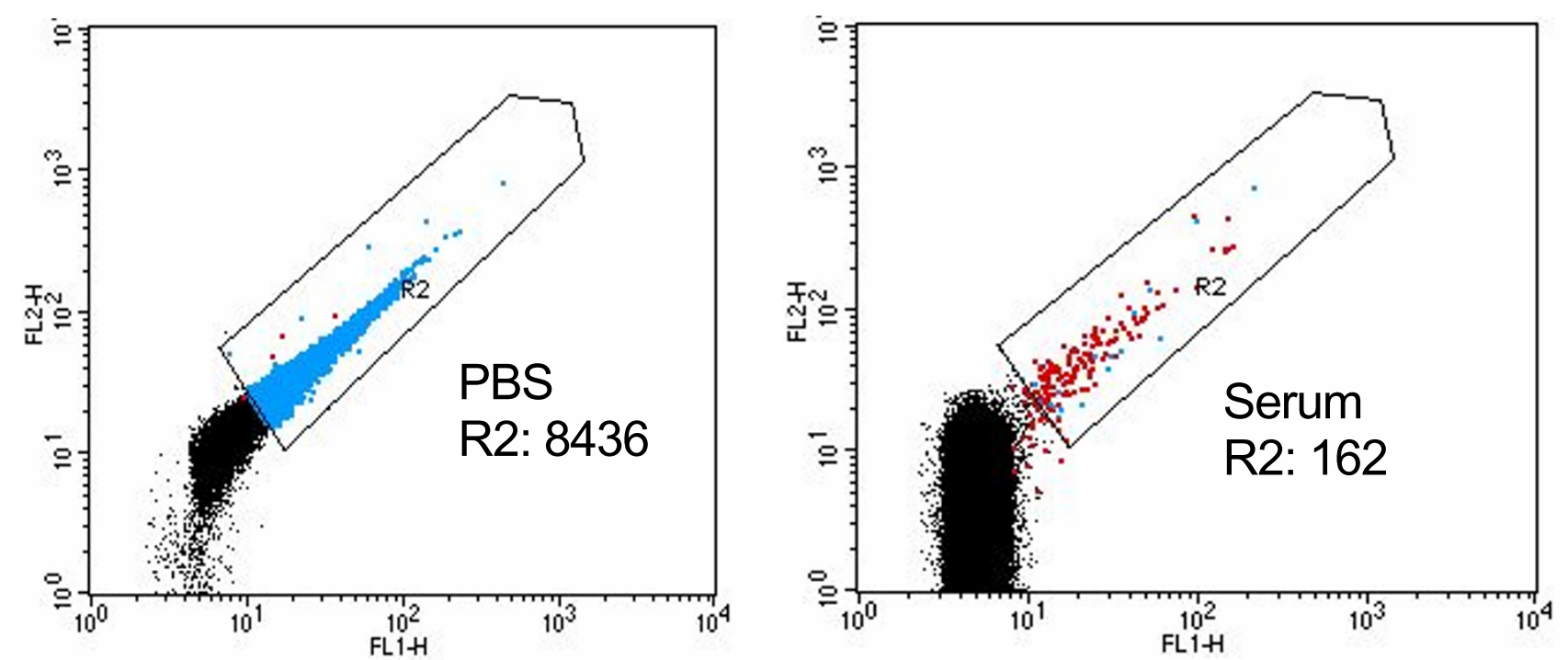

Figure I

Inhibition of PrP aggregation in serum. FITC-labeled recombinant bovine prion protein (concentration $10 \mathrm{nM}$ ) was incubated at $37^{\circ} \mathrm{C}$ for $20 \mathrm{~h}$ with continuous shaking, either in I50 $\mu$ I PBS (left panel) or in the same volume of serum (right panel), followed by flow cytometry. The measurements are depicted in a Fluorescence I (FLI-H) vs. Fluorescence 2 (FL2-H) dot-plot. The number of counts in the area containing specific signals (R2) is given in the figures. Aggregate formation in serum is strongly inhibited. 

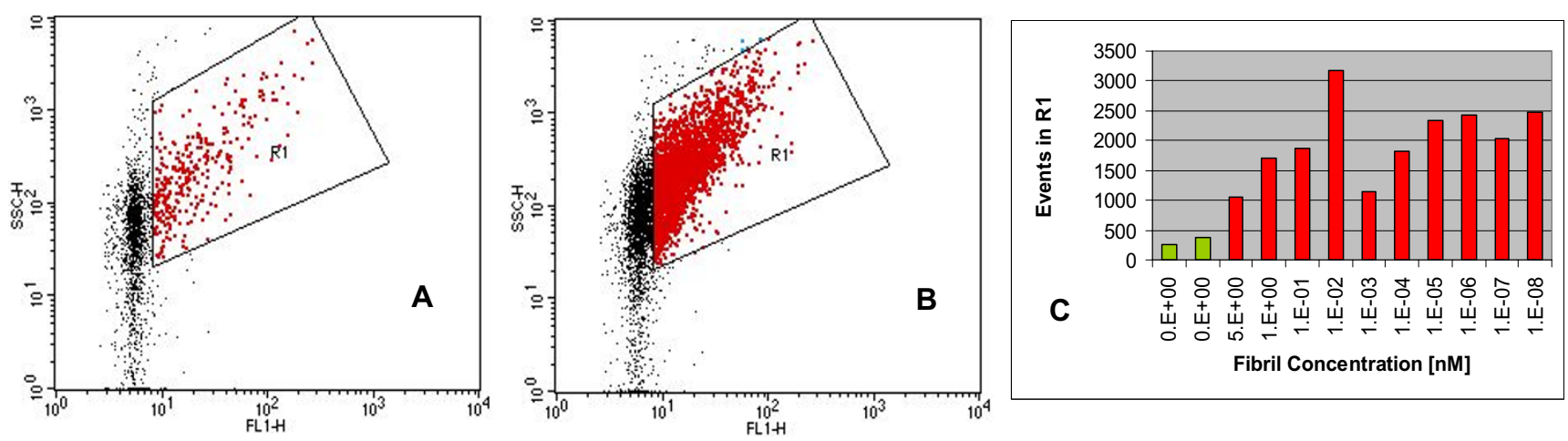

\section{Figure 2}

Seed-dependent PrP aggregate formation in plasma. FITC-labeled recombinant prion protein (5 nM) was incubated in plasma as described in the methods section for $20 \mathrm{~h}$ either in the absence (panel $\mathrm{A}$ ) or presence (panel $\mathrm{B})$ of $10^{-8} \mathrm{nM}$ PrP aggregates. Panel $C$ : quantification of measurements shown in $A$ and $B$, and of measurements (not shown) with different seed concentrations. The measurements are depicted in a Fluorescence I (FLI-H) vs. Side-Scatter (SSC) dot-plot. Aggregate formation (signal in region $\mathrm{RI}$ ) was strongly enhanced by all seed concentrations tested, from $5 \mathrm{nM}$ to $10^{-8} \mathrm{nM}$.

\section{Analysis of serum from clinical-stage, BSE-positive cattle} Studies demonstrating the transmission of prion diseases by blood transfusion suggest that prions are present in the blood of afflicted animals and people, even at pre-symptomatic stages of the disease [16-18]. We used the method of seed-dependent fibril formation to analyze serum from six confirmed cases of clinical-stage, BSE-positive cattle and four controls. Based on the spiking experiments described above, our hypothesis was that any $\mathrm{PrPSc}$ aggregates present in serum may act as seeds for the formation of easily detectable amounts of labeled PrP aggregates, whereas in the absence of seeds the formation of PrP aggregates would be inhibited. The serum samples from BSE-positive cattle and controls from healthy cattle were incubated with $10 \mathrm{nM}$ of a FITC-labeled bovine PrP probe at $37^{\circ} \mathrm{C}$ for $20 \mathrm{~h}$ with continuous shaking, followed by analysis in a flow cytometer. All six BSE-samples could be clearly distinguished by a population of events that was absent in the controls (Fig. 3A-J, green dots in region R3; quantification in fig. $3 \mathrm{~K}$ ).

\section{Conclusion}

We have developed a method based on seed-dependent PrP fibril formation that shows promising results in differentiating a small number of BSE-positive serum samples from healthy controls. More samples need to be tested in order to validate its potential as an ante mortem diagnostic test for BSE and other prion diseases.

\section{Methods \\ Biological fluids}

Serum samples from six confirmed cases of BSE in cattle and four control animals were obtained from BFAV, Insel
Riems, Germany. Control plasma was obtained from a blood bank.

\section{Labeling of prion protein}

Recombinant full-length bovine PrP was produced as described previously $[12,13]$. The purified protein was labeled with a FITC-labeling kit (Roche) according to the manufacturer's instructions.

\section{Preparation of fibrils from recombinant prion protein}

$25 \mu \mathrm{M}$ of unlabeled bovine prion protein in PBS containing $0.2 \%$ SDS was incubated for $10 \mathrm{~min}$ at room temperature, followed by a twentyfold dilution with PBS. For fibril formation, the diluted reaction mixture was incubated for $48 \mathrm{~h}$ at room temperature [14].

\section{PrP fibril formation in serum or plasma}

Recombinant FITC-labeled bovine prion protein was incubated in $150 \mu \mathrm{l}$ serum or plasma at a concentration of 5 or $10 \mathrm{nM}$ for $5-10 \mathrm{~min}$. at $20^{\circ} \mathrm{C}$, shaking at $550 \mathrm{rpm}$ in an Eppendorf thermomixer, followed by an increase of the temperature to $37^{\circ} \mathrm{C} \mathrm{h}$ at constant shaking speed. The incubation was continued for $20 \mathrm{~h}$. Samples were then analyzed by flow cytometry.

\section{Flow cytometry}

Analysis of the samples was carried out on a FACSVantage flow cytometer (BD Biosciences) at room temperature, measurement time was $30 \mathrm{sec}$ per sample.

\section{Authors' contributions}

LT participated in the design of the study, carried out the measurements and drafted the manuscript. ANS participated in the analysis of the data. EM prepared the recom- 


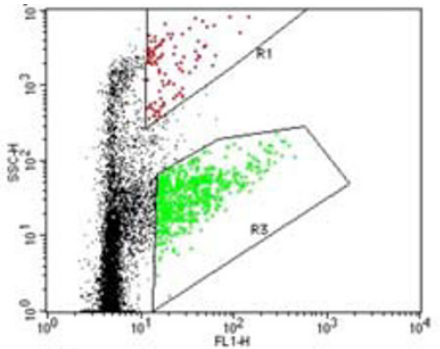

A

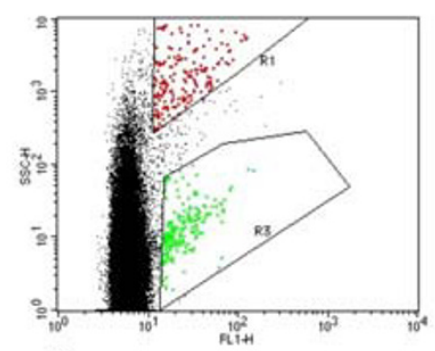

D
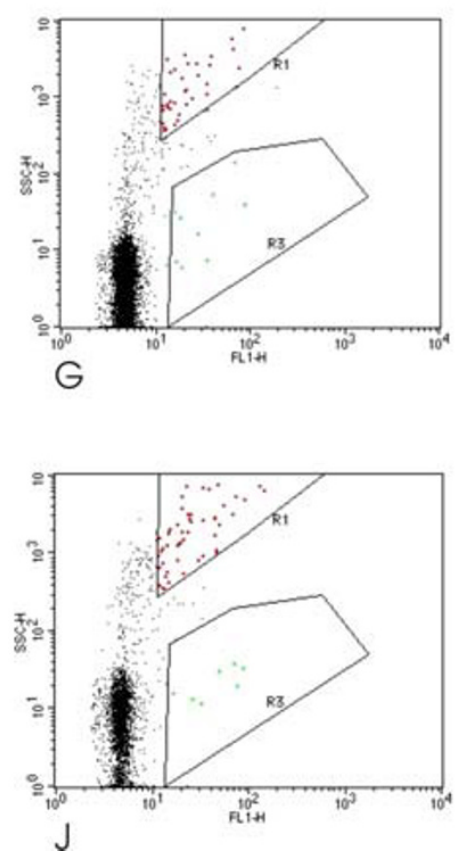

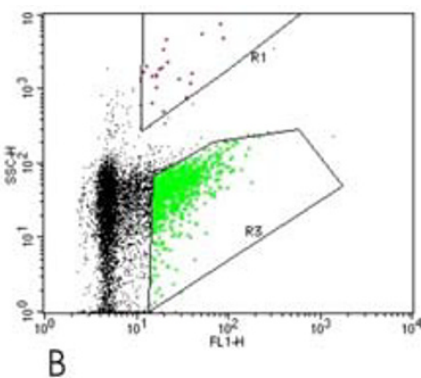

B
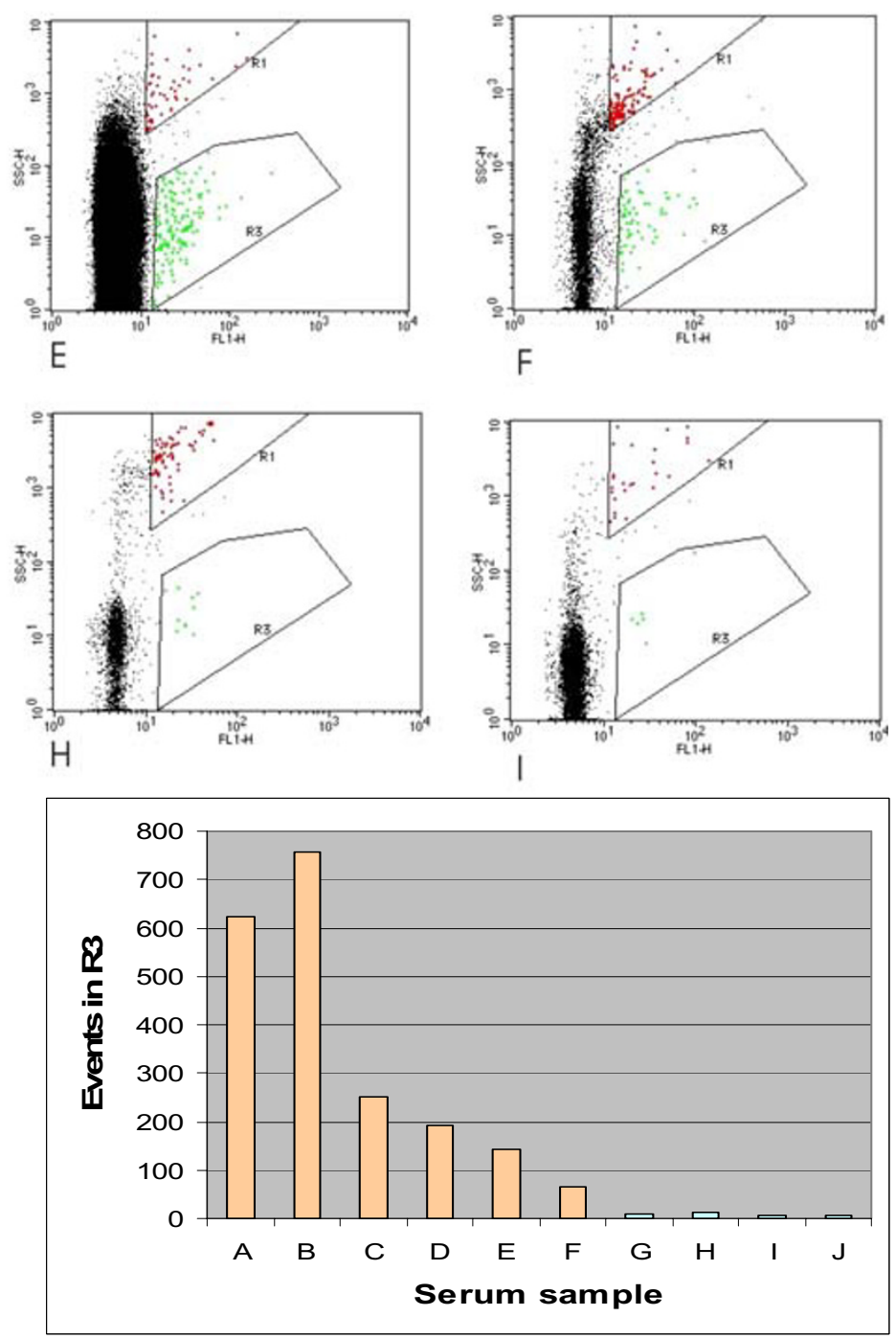

K
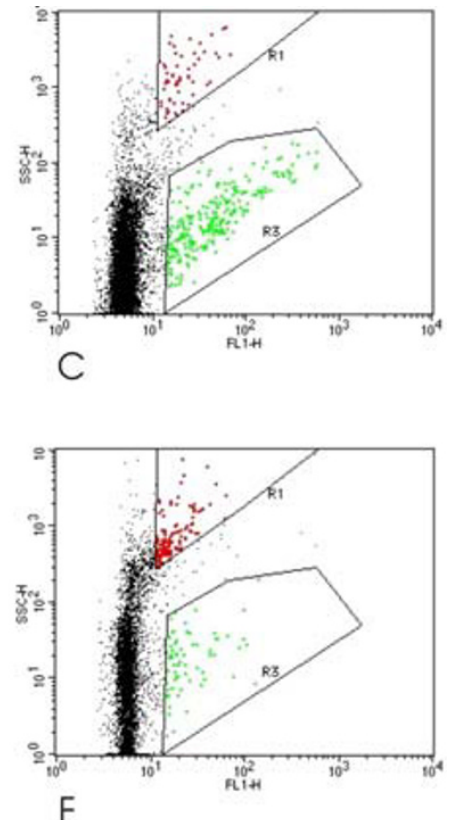

Figure 3

Analysis of serum from BSE-positive cattle. FITC-labeled recombinant prion protein (I0 nM) was incubated in I50 $\mu \mathrm{l}$ of the serum samples as described in the methods section and analyzed by flow cytometry. The measurements are shown in a Fluorescence I (FLI-H) vs. Side-Scatter (SSC) dot-plot. All six BSE-samples (A-F) can be differentiated from the controls (G-J) by a population of events in region R3 (green dots). Panel K: Quantification of measurements shown in panels A-J. 
binant protein. KK and ST were also involved in protein expression and purification. HS participated in the design and coordination of the study. GB conceived of the study and helped to draft the manuscript. All authors read and approved the final manuscript.

\section{Acknowledgements}

This work was kindly supported by grant No. 03 I27IIA from the BMBF (Bundesministerium für Bildung und Forschung) in the context of the German National TSE Research Platform. The authors gratefully acknowledge the help of the TSE Research Platform, Munich, and the BFAV Riems, Germany, with respect to the kind gift of biological material in the context of this study.

\section{References}

I. Prusiner SB: Novel proteinaceous infectious particles cause scrapie. Science 1982, 2 1 6:136-144.

2. Kretzschmar HA, Prusiner SB, Stowring LE, DeArmond SJ: Scrapie prion proteins are synthesized in neurons. Am J Pathol 1986, 1 22: $1-5$.

3. Cashman NR, Loertscher R, Nalbantoglu J, Shaw I, Kascsak RJ, Bolton DC, Bendheim PE: Cellular isoform of the scrapie agent protein participates in lymphocyte activation. Cell 1990, 61:185-192.

4. Manson J, West JD, Thomson V, McBride P, Kaufman MH, Hope J: The prion protein gene: a role in mouse embryogenesis? Development 1992, I I 5: I I7-I 22.

5. Pan KM, Baldwin M, Nguyen J, Gasset M, Serban A, Groth D, Mehlhorn I, Huang Z, Fletterick RJ, Cohen FE, Prusiner SB: Conversion of alpha-helices into beta-sheets features in the formation of the scrapie prion proteins. Proc Natl Acad Sci U S A 1993, 90:10962-10966.

6. Caughey BW, Dong A, Bhat KS, Ernst D, Hayes SF, Caughey WS: Secondary structure analysis of the scrapie-associated protein PrP 27-30 in water by infrared spectroscopy. Biochemistry |99|, 30:7672-7680.

7. Prusiner SB, Groth DF, Bolton DC, Kent SB, Hood LE: Purification and structural studies of a major scrapie prion protein. Cell 1984, 38: | 27-134.

8. Prusiner SB, McKinley MP, Bowman KA, Bolton DC, Bendheim PE, Groth DF, Glenner GG: Scrapie prions aggregate to form amyloid-like birefringent rods. Cell I983, 35:349-358.

9. Prusiner SB: Prions. Proc Natl Acad Sci U S A 1998, 95: I 3363-I 3383.

10. Kretzschmar HA, Ironside JW, DeArmond SJ, Tateishi J: Diagnostic criteria for sporadic Creutzfeldt-Jakob disease. Arch Neurol 1996, 53:913-920.

II. Brown P, Cervenakova L, Diringer $\mathrm{H}$ : Blood infectivity and the prospects for a diagnostic screening test in CreutzfeldtJakob disease. J Lab Clin Med 200I, I37:5-I3.

12. Proske D, Gilch S, Wopfner F, Schätzl HM, Winnacker EL, Famulok $M$ : ion-protein-specific aptamer reduces PrPSc formation. Chembiochem 2002, 3:717-725.

13. Gilch S, Wopfner F, Renner-Muller I, Kremmer E, Bauer C, Wolf E, Brem G, Groschup MH, Schätzl HM: Polyclonal anti-PrP autoantibodies induced with dimeric PrP interfere efficiently with PrPSc propagation in prion-infected cells. I Biol Chem 2003, 278: $18524-18531$.

14. Post K, Pitschke M, Schafer O, Wille H, Appel TR, Kirsch D, Mehlhorn I, Serban H, Prusiner SB, Riesner D: Rapid acquisition of beta-sheet structure in the prion protein prior to multimer formation. Biol Chem 1998, 379:1307-1317.

15. Pitschke M, Prior R, Haupt M, Riesner D: Detection of single amyloid beta-protein aggregates in the cerebrospinal fluid of Alzheimer's patients by fluorescence correlation spectroscopy. Nat Med 1998, 4:832-834.

16. Llewelyn CA, Hewitt PE, Knight RS, Amar K, Cousens S, Mackenzie J, Will RG: Possible transmission of variant Creutzfeldt-Jakob disease by blood transfusion. Lancet 2004, 363:4I7-42I.

17. Peden AH, Head MW, Ritchie DL, Bell JE, Ironside JW: Preclinical vCJD after blood transfusion in a PRNP codon 129 heterozygous patient. Lancet 2004, 364:527-529.
18. Hunter N, Foster J, Chong A, McCutcheon S, Parnham D, Eaton S, MacKenzie C, Houston F: Transmission of prion diseases by blood transfusion. J Gen Virol 2002, 83:2897-2905.
Publish with Biomed Central and every scientist can read your work free of charge

"BioMed Central will be the most significant development for disseminating the results of biomedical research in our lifetime. " Sir Paul Nurse, Cancer Research UK

Your research papers will be:

- available free of charge to the entire biomedical community

- peer reviewed and published immediately upon acceptance

- cited in PubMed and archived on PubMed Central

- yours - you keep the copyright

Submit your manuscript here:

http://www.biomedcentral.com/info/publishing_adv.asp
BioMedcentral 